\title{
MAKNA TRADISI BUDAYA NGANGGUNG DI KABUPATEN BANGKA \\ (STUDI PADA DESA KEMUJA KECAMATAN MENDOBARAT DALAM PERINGATAN MAULID NABI MUHAMMAD SAW)
}

\author{
Rusman, Emi Heningsih \\ STISIPOL PAHLAWAN 12, J1. Diponegoro No. 16, Sungailiat, Bangka 33215 \\ Telp/Fax. (0717) 92750
}

\begin{abstract}
ABSTRAK
Setiap suku bangsa memiliki kebudayaan masing-masing yang berbeda antara budaya yang satu dengan yang lain. Kebudayaan tidak akan ada tanpa adanya kehidupan manusia, yang selalu berhubungan satu sama lain. Proses pembentukan kebudayaan punmembutuhkan waktu yang lama, hal itu menyangkut suatu kebiasaan, baik komunikasi, tindakan atau hasil karya manusia yang menciptakan berbagai adat-istiadat, nilai-nilai atau aturan sosial yang hingga saat ini masih dijadikan sebagai pedoman dalam kehidupan masyarakat yang kaya akan budaya. Masih banyaknya masyarakat Bangka ini tidak memahami tradisi budaya Nganggung, padahal jika diteliti lebih dalam lagi tradisi ini sangat besar perannya dengan status keIslaman di pulau Bangka sampai saat ini. Penelitian ini bertujuan untuk mengetahui makna tradisi budaya Nganggung di Kabupaten Bangka (Studi pada Desa Kemuja kecamatan Mendobarat dalam peringatan Maulid Nabi Muhammad SAW)
\end{abstract}

KATA KUNCI : makna, simbol, interaksionisme simbolik 


\section{PENDAHULUAN}

Setiap suku bangsa memiliki kebudayaan masing-masing yang berbeda antara budaya yang satu dengan yang lain. Keberagaman budaya yang ada di Indonesia dilandasi oleh toleransi hidup yang tinggi. Indonesia juga memiliki semboyan Bhineka Tunggal Ika yang berarti berbeda-beda namun tetap satu jua. Budaya yang terdapat dalam suatu daerah beraneka ragam dan bervariasi. Hal tersebut disebabkan karena sifat budaya itu sendiri turun-temurun dari generasi ke generasi. Provinsi Bangka Belitung merupakan sebuah daerah kepulauan yang terpisah antara pulau Bangka dan Belitung sehingga disatukan menjadi sebuah provinsi yang terdiri dari enam kabupaten terbilang masih muda. Beragam suku bangsa yang terdapat di dalamnya antara lain Melayu, Bugis,Cina, Batak, Buton dan lain-lain. Dan beragam pula budaya yang diyakini oleh setiap suku dan daerah tersebut, tak terkecuali kabupaten Bangka. Kabupaten Bangka adalah kabupaten tertua setelah terbentuknya sebuah provinsi, dimana masyarakatnya beragam suku bangsa yang hidup rukun,damai dan tenteram. Kabupaten Bangka termasuk daerah yang tergolong kaya, selain mempunyai kekayaan alam yang mempuni daerah tersebut juga mempunyai harta warisan nenek moyang terdahulu yang hingga kini masih dijaga akan keberadaannya yaitu kebudayaan.

Kebudayaan tidak akan ada tanpa adanya kehidupan manusia, yang selalu berhubungan satu sama lain. Proses pembentukan kebudayaanpun membutuhkan waktu yang lama, hal itu menyangkut suatu kebiasaan, baik komunikasi, tindakan atau hasil karya manusia yang menciptakan berbagai adat istidat, nilainilai atau aturan sosial yang hingga saat ini masih dijadikan sebagai pedoman dalam kehidupan masyarakat yang kaya akan budaya. Edward
Burnett Tylor mengemukakan kebudayaan adalah kompleks dari keseluruhan pengetahuan, kepercayaan, kesenian, hukum, adat istiadat dan setiap kemampuan lain dan kebiasaan yang dimiliki oleh manusia sebagai suatu anggota suatu masyarakat (Liliweri, 2009:107).

Sedangkan menurut ilmu antropologi kebudayaan adalah keseluruhan sistem gagasan, tindakan dan hasil karya manusia dalam kehidupan masyarakat yang dijadikan milik diri manusia dengan belajar (Koentjaraningrat, 2009: 144). Beranekaragam adat istiadat yang ada Kabupaten Bangka ini, yang merupakan hasil dari kreasi, kebiasaan dan tindakan manusia terdahulu yang sifatnya turun temurun, hal ini ditunjang dengan kebiasaan-kebiasaan dan sikap ramah-tamah masyarakat setempat yang selalu dilakukan, dan simbol-simbol yang dibuat masih utuh seperti sedia kala sehingga nilai-nilai yang terkandung dalam adat tersebut masih terjaga serta memiliki ciri khas. Sebagai salah satu contohnya yaitu tradisi Nganggung. Nganggung adalah kegiatan membawa makanan di dalam dulang ataut alam yang ditutup tudung saji ke masjid, surau, atau balai desa untuk dimakan bersama setelah pelaksanaan acara tahlilan atau doa bersama.

Dalam acara ini, setiap kepala keluarga membawa dulang yaitu sejenis nampan bulat sebesar tampah yang terbuat dari kuningan dan aluminium. Di dalam dulang ini tertata aneka jenis makanan sesuai dengan kesepakatan apa yang harusdibawa. Kalau nganggung kue, yang dibawa kue, nganggung nasi, isi dulang nasi dan lauk pauk, nganggung ketupat biasanya pada saat lebaran. Hidangan ini dikeluarkan dengan rasa ikhlas, bahkan disertai dengan rasa bangga. Nganggung merupakan tradisi yang hingga saat ini masih di junjung tinggi dan dijadikan suatu kebanggaan oleh masyarakat Bangka. Bahkan 
menjadi suatu identitas yang telah melekat dari nenek moyang terdahulu hingga sekarang. Identitas budaya adalah ciri atau khas yang menandai keberadaan kebudayaan itu sendiri. Tradisi Nganggung hanya dilakukan umat muslim dan dilaksanakan setiap ada ritual budaya, peringatan hari besar Islam, adanya anggota masyarakat yang meninggal dan menyambut kedatangan tamu besar yang datang ke sebuah desa.

Nganggung memiliki simbol yang menitipkan suatu makna di dalamnya yang sangat berpengaruh terhadap perilaku masyarakat dalam kehidupan sehari-hari. Makna simbol tersebut dijadikan sebagai acuan untuk saling berinteraksi antar sesama dalam menciptakan kehidupan bermasyarakat yang harmonis. Simbol adalah suatu rangsangan yang mengandung makna dannilai yang dipelajari bagi manusia, dan respon manusia terhadap simbol adalah dalam pengertian makna dan nilainya (Mulyana, 2006: 77). Pierce mengemukakan simbol sebagai tanda yang mengacu pada objekitu sendiri melibatkan tiga unsur mendasar dalam teori segi tiga makna:simbol itu sendiri, satu rujukan atau lebih dan hubungan antara simbol dengan rujukan. Disini dapat dilihat bahwa, hubungan antara simbol sebagai penandadengan sesuatu yang ditandakan (petanda) sifatnya konvensional. Berdasarkan konvesi itu pula masyarakat pemakainya menafsirkan ciri hubungan antara simbol dengan objek yang diacu dan menafsirkan maknanya (Sobur, 2006: 156).

Setiap masyarakat pribumi Bangka tidak ada yang tidak mengenal tradisi Nganggung baik waktu pelaksanaannya, simbol-simbolnya, medianya maupun tujuan pelaksanaannya, hanya penafsiran makna setiap individu masih berbeda. Perbedaan tersebut disebabkan karena kurangnya minat masyarakat untuk menggali dan menganggap hal tersebut kurang penting. Makna Tradisi Nganggung yang berslogan "Sepintu Sedulang" memiliki sebuah pesan yang berunsur simbolis tentang ajaran dan nilai-nilaibagi manusia untuk berkelakuan baik antar sesama dalam kehidupan sehari-hari. Ajaran dan nilainilai tersebut mempunyai hubungan erat dengan ajaran dan nilai-nilai agama Islam. Sama halnya dengan pulau Jawa yang juga memiliki banyak tradisi yang serupa, seperti tradisi kenduri.Kenduri adalah sebuah tradisi yang sudah berjalan sekian puluh tahun,mungkin malah sudah ratusan tahun. Tradisi ini masih banyak berlangsung terutama di desa-desa. Hakekatnya sama, hanya istilahnya saja yang mungkin berbeda. Pada intinya kenduri merupakan mekanisme sosial untuk merawat dan menjaga kebersamaan sehingga cita-cita yang sejak semula dibuat diteguhkan kembali.

Dalam kerangka mekanisme sosial itulah, kenduri menampung dan mepresentasikan banyak kepentingan. Dari sekian banyak kepentingan itu, semua dilebur menjadi satu tujuan. Kenduri mampu mempersatukan, bahkan semakin mempererat kesatuan itu. Bukan hanya kesatuan kepentingan,kesatuan cita-cita, namun juga kesatuan masing-masing individu yang terlibatdidalamnya. Dalam kenduri akan terlihat jelas bagaimana kebersamaan dan keutuhan tercipta, yaitu suasana penuh kerukunan, sendau gurau antarsesama, bagi-bagi berkat dari nasi tumpeng yang baru didoakan, atau ketika bersalam-salaman dengan tulus.

Wujud tradisi kenduri penuh unsur-unsur kepercayaan Animisme-Dinamisme, kemudian ditambahi dengan unsur-unsur Hindu-Budha serta Islam. Setiap penambahan unsur dalam kenduri tentunya akan mengubah sebuah bentuk kenduri, hal ini menunjukkan bahwa segala sesuatu tentulah mengalami perubahan. Sebuah pembaharuan tentu berakibat pada perubahan 
pola kehidupan manusia. Keinginan untuk berinovasi membuat manusia meninggalkan tradisi lama untuk menciptakan tradisi baru. Upacara tradisional merupakan salah satu bentuk tradisi masyarakat Indonesia yang sampai saat ini masih banyak dilaksanakan oleh masyarakat pendukungnya. Peran upacara adalah untuk selalu mengingatkan manusia berkenaan dengan eksistensi dan hubungan dengan lingkungan masyarakat. Sampai sekarang eksistensi sebuah upacara keagamaan masih diakui serta dilaksanakan dengan baik, meskipun dengan bentuk maupun cara yang telah berbeda.

Seiring perkembangan zaman membawa konsekuensi bagi perubahan sosial, maka sistem religi yaitu kenduri juga mengalami pergeseran. Pegeseran tersebut berada pada pemahaman masyarakat terhadap nilai atau makna dari tradisi yang ada, karena pemahaman yang telah berbeda maka wujud tradisi yang dilakukan pun juga berbeda. Pengalaman baru, teknologibaru membuat manusia melakukan penyesuaian cara hidup dan kebiasaanyang baru. Kompasiana, dalam http://sosbud.kompasiana. com/2010/07/31/kenduri-antara-tradisi-danagama208380.html Demikian halnya dengan tradisi Nganggung yang ada di Pulau Bangka ini, baik di perkotaan maupun di pedesaan. Perbedaan pemahaman oleh masyarakat membuat makna dan simbol-simbol tradisi nganggung ini menjadi berubah, hal ini disebabkan perkembangan manusia yang selalu berinteraksi dari waktu ke waktu yang membuat pola fikir dan pola hidup masyarakat berubah. Identitas masyarakat Bangka umumnya dan masyarakat desa Kemuja khususnya mengenai tradisi budaya Nganggung masih utuh adanya walaupun sudah terjadi pergeseran makna dan simbol, akan tetapi tidak menghilangkan makna yang sesungguhnya. Makna tradisi budaya Nganggung yang dijadikan sebagai acuan dalam bertindak akan tetap dipelihara walaupun perkembangan zaman yang sekarang ini semakin maju. Semua itu tidak lepas dari proses komunikasi dan peristiwa budaya,artinya bahwa manusia sebagai makhluk sosial saling berinteraksi walaupun perbedaan ras, suku, dan warna kulit.

Dengan berinteraksi itu pula tercipta persamaan persepsi akan tradisi yang diembannya. sehingga makna yang terkandung di dalam tradisi tersebut terpelihara, apalagi penerapannya dalam kehidupan sehari-hari dan menentukan moralitas setiap individu. Berangkat dari permasalahan itulah peneliti sangat tertarik untuk meneliti lebih dalam Makna Tradisi Budaya Nganggung di Kabupaten Bangka ini, yang pada akhirnya bisa memberikan pengetahuan tentang tradisi budaya daerah khususnya tradisi Nganggung kepada masyarakat Bangka khususnya dan Provinsi Bangka Belitung pada umumnya, sehingga bisa menambah wawasan budaya bagi masyarakat pedesaan maupun kota, dan dijadikan sebagai sarana untuk diadakannya komunikasi antar masyarakat agar bisa tetap meneruskan, menjaga, serta melestarikan budaya yang mereka memiliki agar tidak punah dan memudar sedikit demi sedikit. Dalam penelitian ini peneliti lebih memfokuskan makna tradisi budaya Nganggung dalam pelaksanaan acara peringatan hari besar Islam yaitu peringatan Maulid Nabi SAW di desa Kemuja Kecamatan Mendobarat Kabupaten Bangka.

\section{Pengertian Komunikasi}

Komunikasi merupakan pusat dari seluruh sikap, perilaku dan tindakan yang terampil dari manusia. Manusia tidak bisa dikatakan berinteraksi sosial kalau dia tidak berkomunikasi dengan cara atau melalui pertukaran informasi, ide-ide, gagasan, maksud serta emosi yang 
dinyatakan dalam simbol-simbol dengan orang lain. Liliweri,(2009: 5). Walstrom dalam Liliweri (2009:8) mengemukakan bahwa komunikasi adalah pertukaran pesan-pesan secara tertulis dan lisan atau pertukaran makna antara individu dengan menggunakan sistem simbol yang sama. Dan komunikasi adalah setiap proses pembagian informasi, gagasan atau perasaan yang tidak saja dilakukan secara lisan dan tertulismelainkan melalui bahasa tubuh, atau gaya atau tampilan pribadi, atau hal lain di sekelilingnya yang memperjelas makna.

Sedangkan Bernard, dkk dalam Mulyana (2007: 68) mengemukakan komunikasi adalah transmisi informasi, gagasan, emosi, keterampilan, dan sebagainya, dengan menggunakan simbol-simbol, kata-kata, gambar, figure, grafik dan sebagainya. Jadi dapat disimpulkan bahwa komunikasi tidak lepas dari proses interaksi yang membuat terjadi pertukaran pesan baik melalui simbol-simbol, gambar dan kata-kata.

\section{Pengertian Makna dan Simbol}

\section{a. Makna}

\section{Brown dalam Sobur (2006: 256)} mendefinisikan makna sebagai kecenderungan (disposisi) total untuk menggunakan atau bereaksi terhadap suatu bentuk bahasa. Dan Kempson berpendapat untuk menjelaskan istilah makna harus dilihat dari segi: (1) Kata; (2) Kalimat; dan (3) apa yang dibutuhkan pembicara untuk berkomunikasi. Langer memandang makna sebagai suatu hubungan yang kompleks di antara simbol, objek dan orang. Makna terdiri atas aspek logis dan aspek psikologis. Aspek logis adalah hubungan antara simbol dan referennya yang dinamakan denotasi (denotation), sedangkan aspek atau makna psikologis adalah hubungan antara simbol dengan orang, yang dinamakan konotasi (connotation)(Morissan dkk, 2009: 90).

\section{b. Simbol}

Simbol atau lambang adalah sesuatu yang digunakan untukmenunjuk sesuatu lainnya, berdasarkan kesepakatan kelompok orang (Sobur, 2006: 157). Sedangkan James P. Spradley dalam Sobur (2006: 154) mengemukakan simbol merupakan objek atau peristiwa apapun yang menunjukkan pada sesuatu. K. Langer mengatakan bahwa kebutuhan simbolisasi atau penggunaan lambang merupakan salah satu kebutuhan pokok manusia. Lambang atau simbol adalah sesuatu yang digunakan untuk menunjuk sesuatu lainnya, berdasarkan kesepakatan sekelompok orang. Lambang meliputi kata-kata (pesan verbal), perilaku nonverbal,dan objek yang maknanya disepakati bersama (Mulyana,007: 92). Setiap simbol atau seperangkat simbol menyampaikan suatu konsep, yaitu suatu ide umum, pola atau bentuk. Menurut Langer,konsep adalah makna bersama di antara sejumlah komunikator yang merupakan denotasi dari simbol. Sebaliknya gambaran personal (personal image) adalah pengertian yang bersifat pribadi (privatconception) (Morissan dkk, 2009: 90).

\section{Pengertian Budaya}

Menurut ilmu antropologi, kebudayaan adalah keseluruhan sistem gagasan, tindakan dan hasil karya manusia dalam kehidupan masyarakat yang dijadikan milik diri manusia dengan belajar (Koentjaraningrat, 2009: 144). Sedangkan Edward Burnett Tylor dalam Liliweri (2009: 107) mengemukakan kebudayaan adalah kompleks dari keseluruhan pengetahuan, kepercayaan, kesenian, hukum, adat istiadat dan setiap kemampuan lain dan kebiasaan yang dimiliki oleh manusia sebagai anggota suatu masyarakat. Maka jelaslah bahwa setiap kebiasaan atau tindakan yang dilakukan oleh manusia yang berulang-ulang dengan komunikasi akan 
menjadi sebuah kebudayaan yang hingga kini masih banyak dilakukan oleh masyarakat baik di perkotaan maupun di pedesaan. Kebiasaan budaya tersebut menjadi sebuah identitas bagi masyarakat pengembannya yang memberikan nilai-nilai dan norma dalam kehidupan.

\section{Komunikasi dan Budaya}

Seperti yang telah kita ketahui bahwa komunikasi merupakan suatu proses interaksi antar manusia baik kelompok, ras, etnik ataupunbudaya lain. Ini menandakan bahwa komunikasi merupakan hal yang mendasar dalam kehidupan manusia. Jane Pauley (1999) dalamLiliwer (2009: 7) mengemukakan komunikasi merupakan transmisi informasi, transmisi pengertian yang menggunakan simbolsimbol yang sama.Sedangkan kebudayaan atau budaya menurut Edward Burnett Tylor adalah bahwa kebudayaan adalah komplek dari keseluruhan pengetahuan, kepercayaan, kesenian, hukum, adat istiadat dan setiap kemampuan lain dan kebiasaan yang dimiliki oleh manusia sebagai anggota suatu masyarakat (Liliweri, 2003: 107). Dan dalam ilmu antropologi, kebudayaan adalah keseluruhan sistem gagasan, tindakan dan hasil karya manusia dalam kehidupan masyarakat yang dijadikan milik diri manusia dengan belajar (Koentjaraningrat, 2009:144).

Komunikasi dan budaya merupakan dua hal yang saling berhubungan. Seperti apa yang dikatakan Smith (1976) bahwa "komunikasi dan kebudayaan tidak dapat dipisahkan." Atau Edward T. Hall mengatakan "komunikasi adalah kebudayaan dan kebudayaan adalah komunikasi." Artinya dalam kebudayaan ada sistem dan dinamika yang mengatur tata cara pertukaran simbol-simbol komunikasi dan hanya dengan komunikasi maka pertukaran simbolsimbol dapat dilakukan (Liliweri, 2009: 21).

\section{Pengertian Motif}

Menurut Suradinata (1996: 129) bahwa, motif adalah suatudorongan yang ada dalam diri sendiri untuk berbuat sesuatu baikberupa gerakan maupun ucapan. Sedangkan Purwadarminta (1991:655) mengemukakan bahwa motif adalah sebab-sebab yang menjadi dorongan tindakan seseorang; dasar pikiran atau pendapat; sesuatu yang menjadi pokok.

\section{Pengertian Adat-istiadat, Kebiasaan/Tradisi dan Pelestarian Budaya}

\section{a. Adat-Istiadat}

Adat istiadat adalah himpunan kaidah sosial yang sudah sejak lama ada dan merupakan tradisi serta lebih banyak berbau sakral,mengatur tata kehidupan masyarakat tertentu. Adat istiadat hidupdan berkembang di masyarakat tertentu dan dapat menjadi hukum adat jika mendapat dukungan sanksi hukum.Menurut para ahli bahwa Adat-istiadat adalah sistem norma yang tumbuh, berkembang dan dijunjung tinggi oleh masyarakat penganutnya. Pengertian ahli dalam http://www.pengertianahli.com/p/blogpage_20. Html.

\section{b. Pengertian Kebiasaan/ Tradisi}

Kebiasaan adalah perbuatan manusia yang tetap dilakukan berulang-ulang dalam hal yang sama. Apabila suatu kebiasaan tertentu diterima oleh masyarakat dan kebiasaan itu selalu berulangulang dilakukan sedemikan rupa, sehingga tindakan yang berlawanan dengan kebiasaan itu dirasakan sebagai pelanggaran perasaan hukum, maka dengan demikian timbullah suatu kebiasaan hukum, yang oleh pergaulan hidup dipandang sebagai hukum. Arif Sobarudin dalam http:// www.bisosial.com/2012/11/kebiasaancustom. html. Tradisi (Bahasa Latin: traditio, “diteruskan") atau kebiasaan, dalam pengertian 
yang paling sederhana adalah sesuatu yang telah dilakukan untuk sejak lama dan menjadi bagian dari kehidupan suatu kelompok masyarakat, biasanya dari suatu negara, kebudayaan, waktu, atau agama yang sama. Hal yang paling mendasar dari tradisi adalah adanya informasi yang diteruskan dari generasi ke generasi baik tertulis maupun (sering kali) lisan, karena tanpa adanya ini, suatu tradisi dapat punah. Wikipedia dalam http:// id. wikipedia. org/ wiki/ Tradisi.

\section{c. Pengertian Pelestarian Budaya}

Menurut Martha Gunawan pelestarian budaya jika dilihat darisegi pemaknaan kata dasarnya dalam kamus besar bahasa Indonesia (KBBI), yaitu berarti tetap seperti keadaan semula, tidak berubah,kekal. Hal ini menandakan bahwa pelestarian kebudayan itu dimaknai "menjadikan membiarkan tetap tidak berubah, membiarkan tetap seperti keadaannya semula, mempertahankan kelangsungannya."

Di lain sisi menurut M.J Herskovits dalam Martha Gunawan berpandangan bahwa setiap kebudayaan tumbuh dan berkembang secara dinamis, sehingga berlandaskan akan hal ini, beliau berpandangan bahwa pelestarian kebudayaan pada hakekatnya tidaklah menghalang-halangi perubahan termasuk yang ditimbulkan oleh penerimaan unsurunsur kebudayaan luar, apalagiyang diperlukan dalam upaya peningkatan harkat serta kualitas hidup bangsa. Martha Gunawan dalam http:// marthagunawan.blogspot. com/2012/06/ maknapelestarian-budaya. html.

\section{Tradisi Nganggung}

Tradisi Nganggung adalah suatu kegiatan membawa dulang bertutupkan tudung saji dan berisikan berbagai aneka jenis makanan yang dibawa ke masjid atau mushola sesuai dengan hasil kesepakatan bersama dalam masyarakat. Tradisi Nganggung dapat dikatakan salah satu identitas Bangka, sesuai dengan slogan Sepintu Sedulang, yang mencerminkan sifat kegotongroyongan, berat sama dipikul ringan sama dijinjing.

Nganggung atau Sepintu Sedulang merupakan warisan nenek moyang yang mencerminkan suatu kehidupan sosial masyarakat berdasarkan gotong-royong. Jaka Filyamma dalam http://jakafilyamma.blogspot. com/2012/09/nganggung-tradisi-bangkabelitung.html. Tradisi Nganggung dilaksanakan pada setiap datangnya harihari besar Islam, namun tidak demikian adanya, sekarang pelaksanaan nganggung ini sudah berkembang, salah satunya adalah nganggung ketika ada salah satu warga yang meninggal dan kedatangan tamu besar dalam jumlah yang besar juga.

\section{Perayaan Maulid Nabi}

Hari besar Islam merupakan hari yang sakral bagi penganutnya,seperti peringatan Satu Muharam, Maulid Nabi Muhammad SAW, Isra'Mi'raj Nabi Muhammad SAW, Idul Fitri dan Idul Adha. Setiap umat muslim pasti mengetahui dan memperingati hari-hari tersebut, hanya saja bentuk peringatannya tidak sama setiap daerah. Maulid Nabi Muhammad SAW kadang-kadang disebut Maulid Nabi atau Maulud saja (bahasa Arab, mawlid an-nab_) adalah peringatan hari lahir Nabi Muhammad SAW, yang di Indonesia perayaannya jatuh pada setiap tanggal 12 Rabiul Awal dalam penanggalan Hijriyah. Kata maulid atau milad dalam bahasa Arab berarti hari lahir. Perayaan Maulid Nabi merupakan tradisi yang berkembang di masyarakat Islam jauh setelah Nabi Muhammad SAW wafat. Secara subtansi, peringatan ini adalah ekspresi kegembiraan dan penghormatan kepada Nabi Muhammad SAW. 
Dari Wikipedia bahasa Indonesia, ensiklopedia bebas dalam http://id.wikipedia.org/wiki/ Maulid_Nabi_Muhammad.

Peringatan Maulid Nabi Muhammad saw. Ketika tibanya waktu peringatan tersebut setiap yang beragama Islam pasti melaksanakan kegiatan yang berbau Islam. Hal ini seperti yang telah dilakukan oleh segenap masyarakat Provinsi Bangka-Belitung dan kabupaten Bangka khususnya desa Kemuja kecamatan Mendobarat. Setiap peringatan Maulid Nabi di desa Kemuja selalu dirayakan secara besar-besaran, malah melebihi perayaan lebaran Idul Fitri dan Adha. Seperti yang terlihat pada kemeriahan Maulid Nabi di Masjid Rahmattudin desa Kemuja, diwarnai dengan adanya Festival Seni Budaya Islam (FSBI) tahun 2014 dan Tabligh Akbar Harlah Nahdatul Ulama ke-88 oleh KH Manarul Hidayat. Dan masih banyak lagi kegiatan yang diselenggarakan oleh masyarakat desa Kemuja yaitu lomba adzan tingkat anak-anak, musabaqoh tilawatil Al-qur'an (usia5-8 tahun), musabaqoh fahmil Al-qur'an (cerdas cermat/ SD/ Mi) dan Hafdizul Al-qur'an (usia 5-8 tahun)

\section{Teori Interaksi Simbolik}

Teori interaksi simbolik adalah salah satu cabang dalam teori sosiologi yang mengemukakan tentang diri sendiri (the self) dan dunialuarnya. Di sini Cooley menyebutnya sebagai looking glass self. Artinya setiap hubungan sosial dimana seseorang itu terlibat merupakan satu cerminan diri yang disatukan dalam identitas orangitu sendiri. Jadi maksudnya kita bisa melihat atau mengoreksi diri kita dengan melalui orang lain. Esensi dari teori ini adalah simbol dan makna. Makna adalah hasil dari interaksi sosial. Ketika kita berinteraksi dengan orang lain, kita berusaha mencari makna yang cocok dengan orang tersebut. Kita juga berusaha mengintepretasikan maksud seseorang melalui simbolisasi yang dibangun. Nur Dewi Setyowati dalam http:// detaachtiana.blogspot.com/2013/04/reviewteori- interaksionismesimbolik.html.

Sesuai dengan pemikiran Mead, definisi singkat dari tiga ide dasar interaksi simbolik. Nur Dewi Setyowati di http:// detaachtiana.blogspot. com/2013/04/review-teori-interaksionismesimbolik.html.

a. Mind (pikiran): Kemampuan untuk menggunakan simbol yang mempunyai makna sosial yang sama, dimana tiap individu harus mengembangkan pikiran mereka melalui interaksi dengan individu lain.

b. Self (diri pribadi): Kemampuan untuk merefleksikan diri tiap individu dari penilaian sudut pandang atau pendapat orang lain,dan teori interaksionisme simbolis adalah salah satu cabang dalam teori sosiologi yang mengemukakan tentang diri sendiri (the-self) dan dunia luarnya.

c. Society (masyarakat): Hubungan sosial yang diciptakan, dibangun,dan dikonstruksikan oleh tiap individu di tengah masyarakat, dan tiap individu tersebut terlibat dalam perilaku yang mereka pilih secara aktif dan sukarela, yang pada akhirnya mengantarkan manusia dalam proses pengambilan peran di tengah masyarakatnya.

Tiga tema konsep pemikiran George Herbert Mead yang mendasari interaksi simbolik antara lain: a. Pentingnya makna bagi perilaku manusia, Tema ini berfokus pada pentingnya membentuk makna bagi perilaku manusia, dimana dalam teori interaksi simbolik tidak bisa dilepaskan dari proses komunikasi, karena awalnya makna itu tidak ada artinya, sampai pada akhirnya di konstruksi secara interpretif oleh individu melalui proses interaksi, untuk menciptakan makna yang dapat 
disepakati secara bersama dimana asumsi-asumsi itu adalah sebagai berikut: Manusia, bertindak, terhadap, manusia, lainnya berdasarkan makna yang diberikan orang lain kepada mereka, Makna diciptakan dalam interaksi antar manusia, Makna dimodifikasi melalui proses interpretif.

a. Pentingnya konsep mengenai diri (self concept)Tema ini berfokus pada pengembangan konsep diri melalui individu tersebut secara aktif, didasarkan pada interaksi sosial dengan orang lainnya dengan cara antara lain: Individu-individu mengembangkan konsep diri melalui nteraksi dengan orang lain. Konsep diri membentuk motif yang penting untuk perilaku. Mead seringkali menyatakan hal ini sebagai: "The particular kind of rolethinking - imagining how we look to another person" or "ability tosee ourselves in the reflection of another glass".

b. Hubungan antara individu dengan masyarakat.Tema ini berfokus pada dengan hubungan antara kebebasan individu dan masyarakat, dimana norma-norma sosial membatasi perilaku tiap individunya, tapi pada akhirnya tiap individu-lah yang menentukan pilihan yang ada dalam sosial kemasyarakatannya. Fokus dari tema ini adalah untuk menjelaskan mengenai keteraturan dan perubahan dalam proses sosial. Asumsi-asumsi yang berkaitan dengan tema ini adalah orang dan kelompok masyarakat dipengaruhi oleh proses budaya dan sosial, Struktur sosial dihasilkan melalui interaksi sosial. Blumer dalam Kuswarno (2009: 113) mengungkapkan tiga premis yang mendasari pemikiran interaksionisme simbolik, yaitu (1) Manusia bertindak terhadap sesuatu berdasarkan makna-makna yang ada pada sesuatu itu bagi mereka, (2) Makna tersebut berasal dari "interaksi sosial seseorang dengan orang lain", dan (3) Makna-makna tersebut disempurnakan di saat proses interaksi sosial berlangsung. Menurut
Blumer, masyarakat tidak tersusun dari struktur makro. "Masyarakat terdiri dari manusia yang bertindak, dan kehidupan masyarakat dapat dilihat sebagai terdiri dari tindakan mereka". Jadi maksudnya kehidupan dalam suatu masyarakat dipandang baik atau buruk oleh orang lain adalah tergantung dari tindakan anggota masyarakatnya. Tindakan manusia sebagai individu dalam suatu kelompok/masyarakat menentukan kehidupan masyarakatnya.

Blumer juga mempunyai asumsi dasar interaksi simbolik yang dikembangkan dari ide-ide/pemikiran dasar Mead. Yaitu, manusia bertindak terhadap orang lain berdasarkan makna yang diberikan orang lain pada mereka, Makna diciptakan dalam interaksi antarmanusia, Makna dimodifikasi melalui sebuah proses interpretif,Individu-individu mengembangkan konsep diri melalui interaksi dengan orang lain, Konsep diri memberikan sebuah motif penting untuk berperilaku, orang dan kelompokkelompok dipengaruhi oleh proses budaya dan sosial, Struktur sosial dihasilkan melalui interaksi sosial. Melihat ketiga premis dan ketujuh asumsi di atas terdapat esensi bahwa komunikasi atau pertukaran simbol yang diberi makna merupakan suatu aktivitas yang khas diantara manusia. Mead menjelaskan bahwa kemampuan manusia untuk dapat merespon simbol-simbol diantara mereka ketika berinteraksi, membawa penjelasan interaksionisme simbolik kepada konsep tentang diri (self). Dan secara sosial seseorang dapat melakukan tindakan kepada dirinya sendiri, seperti juga kepada orang lain (Kuswarno, 2009: 144). Esensi interaksi simbolik adalah suatu aktifitas yang merupakansuatu ciri khas manusia, yakni komunikasi atau pertukaran simbol yang diberi makna (Mulyana, dalam Sobur, 2006: 197). 


\section{Lokasi Penelitian}

Penelitian ini dilakukan di desa Kemuja kecamatan Mendobarat, kabupaten Bangka. Karena disamping desa tersebut merupakan desa santrisantriwati, Desa ini juga pernah mendapatkan rekor muri dalam pelaksanaan tradisi Nganggung untuk kategori penyajian makanan terbanyak yang terdiridari 10.700 dulang dan peserta terbanyak dalam acara pendukung pembacaan Berzanji.

\section{Jenis Penelitian}

Jenis yang digunakan dalam penelitian ini adalah metode penelitian kualitatif pendekatan fenomenologi yang bertujuan untuk mengetahui dunia dari sudut pandang orang yang mengalami secara langsung atau berkaitan dengan sifat-sifat alami pengalaman manusia, dan makna yang ditempelkan padanya (Kuswarno, 2009: 35).

\section{Jenis dan Sumber Data Jenis Data}

Untuk mendukung penelitian ini, peneliti menggunakan dua jenis data yaitu data primer dan data sekunder. Data primer, atau data tangan pertama adalah data yang diperoleh langsung dari subjek penelitian

dengan mengenakan alat pengukuran atau alat pengambilan data langsung pada subjek sebagai sumber informasi yang dicari. Data sekunder atau data tangan ke dua adalah data yang di peroleh lewat pihak lain, tidak langsung diperoleh oleh peneliti dari subjek penelitiannya dalam (Saifuddin A. 2007: 91).

\section{Sumber Data}

Sumber data adalah benda, hal atau orang tempat peneliti mengamati, membaca atau bertanya tentang data (Arikunto, 2005: 88). Sumber data tersebut adalah benda-benda yang menjadi simbol budaya nganggung, tokoh agama atau masyarakat, buku-buku atau tulisan yang berhubungan dengan penelitian penulis.

\section{Teknik Pengumpulan Data}

Teknik pengumpulan data merupakan suatu cara yang digunakan untuk memperoleh atau mengumpulkan data yang dibutuhkan dalam penelitian. Untuk memperoleh data yang sesuai dengan permasalahan diperlukan teknik pengumpulan data. Teknik pengumpulan data yang digunakan dalam penelitian ini antara lain:

\section{Observasi Non partisipan}

Observasi adalah metode dimana peneliti mengamati langsung objek yang diteliti. Dalam penelitian ini penulis memilih jenis Observasi Nonpartisipan yaitu dimana penulis tidak memposisikan dirinya sebagai anggota kelompok yang diteliti (Kriyantono, 2006: 65).Proses kegiatan ini lebih ditekankan pada ketelitian dan kejelian peneliti sendiri. Dalam observasi ini, peneliti melakukan pengamatan secara langsung tempat yang akan digunakan untuk penelitian seperti pelaksanaan kegiatan tradisi Nganggung yang sedang berlangsung. Misalnya perilaku, benda, dan warna atau corak yang digunakan oleh pelaku budaya itu sendiri.

\section{Wawancara Mendalam}

Wawancara mendalam adalah penelitian dimana peneliti melakukan kegiatan wawancara tatap muka secara mendalam dan terus-menerus (lebih dari satu kali) untuk menggali informasi dari narasumber. Karena itu, narasumber disebut juga informan. Karena wawancara dilakukan lebih dari sekali, maka disebut juga "intensive interviews" dalam (Kriyantono, 2006: 65).Wawancara diadakan dengan tujuan untuk memperoleh data yang diperlukan, untuk 
mengecek kebenaran data yang diperoleh peneliti melalui kegiatan observasi yang dilakukan pada langkah pertama. Pada tahap wawancara ini, peneliti mendengarkan dengan seksama penjelasan para sesepuh atau tokoh masyarakat yang ada di daerah tersebut tentang tradisi budaya ngganggung.

\section{Studi Kepustakaan (Library Research)}

Studi kepustakaan merupakan teknik pengumpulan data dengan mencari sumber dan literatur yang berhubungan dengan penelitian yang akan dilakukan. Misalnya berupa dokumen, buku, internet, koran harian, foto-foto dan sebagainya.

\section{HASIL DAN PEMBAHASAN}

Penelitian ini bertujuan untuk mengetahui bagaimana interaksi simbolik dalam pelaksanaan tradisi Nganggung di desa Kemuja kecamatan Mendobarat. Tradisi nganggung yang masih dilestarikan oleh masyarakat Desa Kemuja memiliki pemaknaan pada simbol, baik simbol peralatan maupun simbol tindakan. Interaksi simbolik mengacu pada setiap tindakan manusia yang bermakna berdasarkan simbol-simbol tradisi budaya nganggung yang memiliki makna dan simbol-simbol selalu mengalami perkembangan seiring waktu, hal ini disebabkan manusiadalam perkembangannya selalu berubahubah baik pola pikirnya, tindakannya dan tingkat pemahamannya akan sesuatu, tak terkecuali tradisi budaya sehingga pergeseran budaya pun tak terelakkan. Semua itu tidak lepas darisebuah proses interaksi manusia antar sesama.

Untuk mengumpulkan data dalam penelitian ini peneliti menggunakan cara wawancara mendalam. Sasaran yang diwawancarai merupakan warga asli desa Kemuja dan warga luar Bangka yang telah lama menetap di desa
Kemuja. Untuk warga asli desa Kemuja terdiri dari enam narasumber yang peneliti pilih bisa mewakili dan dianggap masyarakat sekitar lebih memahami dan selalu menerapkan tentang budaya Nganggung, narasumber tersebut merupakan sesepuh, tokoh masyarakat, tokoh agama, tokoh pemuda, sekdes Kemuja dan masyarakat biasa. Dan warga luar bangka terdiri dari dua narasumber dan termasuk masyarakat biasa yang sering ikut berpartisipasi dalam melaksanakan nganggung. Dalam penelitian ini peneliti lebih memfokuskan kepada fokus penelitian tentang motif tradisi Nganggung, makna simbol tradisi nganggung dan implementasinya dalam kehidupan seharihari. Masyarakat desa Kemuja memiliki motif dalam pelaksaan tradisi budaya nganggung ini, berikut motif masyarakat desa Kemuja dalam pelaksanaan tradisi budaya nganggung.

\section{Motif Tradisi Nganggung Analisa Data}

Berdasarkan hasil penelitian di atas maka untuk selanjutnya penelitian akan menganalisa hasil penelitian tersebut sesuai dengan fokus penelitian tentang motif, makna dan implementasi tradisi nganggung di desa Kemuja kecamatan Mendobarat Kabupaten Bangka pada peringatan Maulid Nabi Muhammad SAW. Tradisi budaya nganggung merupakan hasil karya manusia yang telah dibiasakan berulang-ulang hingga sekarang. Tradisi nganggung juga memiliki simbol-simbol yang mengandung makna. Dalam pelaksanaannya tentu memiliki tujuan yang diharapkan agar makna dan simbol tersebut terpelihara sesuai dengan kesepakatan yang telah ditentukan. Manusia sebagai makhluk sosial tidak lepas dari proses komunikasi. Komunikasi merupakan penyambung antar anggota masyarakat, dimana mereka akan menjauhkan dari hal-hal yang menyebabkan kerusakan dalam masyarakat. Kehidupan sosial manusia 
yang selalu berinteraksi dapat membangun, memelihara dan mengubah kebiasaan-kebiasaan, termasuk di dalamnya adalah bahasa dan simbolsimbol. Setiap bahasa maupun simbol-simbol memiliki makna yang berguna bagi manusia itu. Makna bahasa dan simbol-simbol merupakan hasil interaksi antar masyarakat. Kesemuanya itu dijadikan sebuah simbol yang bermakna sehingga manusia berinteraksi berdasarkan simbol yang telah dibuat, seperti apa yang dikatakan Mead bahwa esensi dari teori interaksi simbolik adalah simbol dan makna. Makna adalah hasil dari interaksi sosial. Tradisi budaya Nganggung yang merupakan hasil interaksi masyarakat Bangka tidak lepas dari pemikiran manusia.

\section{Motif Tradisi Nganggung}

Tradisi nganggung yang dilaksanakan masyarakat desa Kemuja kecamatan Mendobarat merupakan suatu kebiasaan yang telah menjadi adat dan istiadat di wilayah tersebut. Masyarakat desa Kemuja menganggap bahwa adat dan istiadat nganggung ini merupakan suatu kekayaan masyarakat pulau Bangka yang tidak bisa ditukar dengan suatu apapun karena makna di dalamnya terkandung ajaran Islam.

Tradisi nganggung yang telah dijadikan sebagai identitas oleh masyarakat desa Kemuja pasti mempunyai motif dalam pelaksanaannya. Terkadang setiap masyarakat tidak sama dalam menafsirkan makna yang ada, sehingga motifnya dalam melaksanakan tradisi Nganggung ini berbeda. Menurut Suradinata (1996: 129) bahwa motif adalah suatu dorongan yang ada dalam diri sendiri untuk berbuat sesuatu baik berupa gerakan maupun ucapan. Sedangkan Purwadarminta (1991: 655)

Mengemukakan bahwa motif adalah sebabsebab yang menjadi dorongan tindakan seseorang; dasar pikiran atau pendapat; sesuatu yang menjadi pokok. Motif masyarakat desa Kemuja dalam melaksanakan tradisi nganggung adalah sebagai upaya pelestarian budaya dan karena kebiasaan adat-istiadat. Jadi jelas bahwa motif tersebut dijadikan suatu dorongan sosial bagi masyarakat untuk bertindak dan berperan serta dalam melestarikan budaya. Hal ini sesuai dengan hasil wawancara dan hasil observasi peneliti bahwa terlihat setiap kepala keluarga masyarakat desa Kemuja ikut melaksanakan dan berpartisipasi dalam mensukseskan kegiatan nganggung pada peringatan Maulid Nabi Muhammad SAW.

Kebiasaan pelaksanaan kegiatan nganggung di desa Kemuja juga terlihat dari interaksi antar sesama, tata cara membawa dulang, pembacaan sholawat sampai berdo'a bersama utuh setiap tahunnya tanpa ada perubahan. Hal ini membuktikan bahwa masyarakat desa Kemuja berupaya memelihara dan melestarikan adat-istiadat yang telah dititipkan oleh orang terdahulu. Motif masyarakat desa Kemuja dalam melaksanakan tradisi nganggung sebagai upaya pelestarian budaya. Menurut Martha Gunawan pelestarian budaya jika dilihat dari segi pemaknaan kata dasarnya dalam kamus besar bahasa Indonesia (KBBI), yaitu tetap seperti keadaan semula, tidak berubah, kekal. Hal ini menandakan bahwa pelestarian kebudayan itu dimaknai "menjadikan membiarkan tetap tidak berubah, membiarkan tetap seperti keadaannya semula, mempertahankan kelangsungannya."

Dilain sisi menurut M.J Herskovits, Martha Gunawan juga mengungkapkan tentang pelestarian budaya bahwa setiap kebudayaan tumbuh dan berkembang secara dinamis, sehingga berlandaskan akan hal ini, beliau berpandangan bahwa pelestarian kebudayaan pada hakekatnya tidaklah menghalang-halangi perubahan termasuk yang ditimbulkan oleh 
penerimaan unsur-unsur kebudayaan luar, apalagi yang diperlukan dalam upaya peningkatan harkat serta kualitas hidup bangsa. Martha Gunawan dalam http://marthagunawan.blogspot.com/ 2012/06/ makna-pelestarian-budaya. html.

Tradisi nganggung yang ada di desa Kemuja telah mengalami perubahan seiring berkembangnya manusia dari waktu ke waktu. Perubahan itu disebabkan berkembangnya pola pikir masyarakat, pengaruh globalisasi dan banyaknya budaya-budaya yang masuk sehingga akulturasi pun tak terelakkan. Akan tetapi tidak menghilangkan pemaknaan yang sesungguhnya. Hal ini sesuai dengan pandangan M.J Herkovits diatas bahwa setiap kebudayaan tumbuh dan berkembang secara dinamis, sehingga berlandaskan akan hal-hal.

Setiap budaya pasti memiliki kebiasaan, begitu pula dengan budaya nganggung yang juga memiliki kebiasaan. Kebiasaan adalah perbuatan manusia yang tetap dilakukan berulang-ulang dalam hal yang sama. Sobarudin dalam http:// www.bisosial.com/2012/11/kebiasaancustom. html. Kebiasaan sama halnya dengan tradisi. Kebiasaan atau tradisi nganggung yang dilakukan oleh masyarakat desa Kemuja sesuai dengan adat-istiadat yang telah ditetapkan. Artinya kebiasaan yang telah dibuat oleh orang tua terdahulu masih tetap dilakukan walaupun terjadi pergeseran yang bersifat tidak menghilangkan pemaknaannya. Kebiasaan merupakan salah satu motif masyarakat desa Kemuja dalam pelaksanaan budaya nganggung. Kebiasaan atau tradisi nganggung yang telah lama dilakukan oleh tetuah terdahulu ternyata memilliki daya tarik dan meresap pada memori masyararakat desa Kemuja. Betapa tidak berdasarkan hasil pengamatan peneliti bahwa kebiasaan-kebiasaan tradisi nganggung yang telah dilakukan ini dapat menumbuhkan karakter setiap individu akan hal kebaikan. Hal kebaikan disini adalah peranan sosial setiap individu untuk memakmurkan warga setempat dan kualitas hidup. Di lain sisi bahwa dengan kebiasaan tersebut secara tidak langsung telah memegang teguh amanah yang telah dititipkan para pendahulu. Serta dapat dijadikan acuan untuk para generasi yang akan datang.

Kebiasaan atau tradisi terlahir dari sebuah adat-istiadat. Menurut para ahli bahwa adatistiadat adalah sistem norma yang tumbuh, berkembang dan dijunjung tinggi oleh masyarakat penganutnya. Pengertian ahli dalamhttp://www. pengertianahli.com/p/blogpage_20.Html. Adatistiadat masyarakat desa Kemuja adalah aturan tentang pelaksanaan tradisi nganggung yang telah ditetapkan berdasarkan hasil musyawarah untuk kepentingan bersama. Contohnya kegiatan tradisi nganggung pada setiap peringatan hari Maulid Nabi harus selalu dirayakan, pelaksanaan pada tiap hari besar Islam, pelaksanaannya juga ketika adanya warga yang meninggal, dan penetapan alat yang digunakan seperti dulang dan tudung saji. Motif pelaksanaan tradisi nganggung masyarakat desa Kemuja mengenai adat-istiadat menunjukkan bahwa masih kentalnya jiwa sosial setiap individu akan kebudayaan. Secara garis besar peneliti berpendapat bahwa masyarakat desa Kemuja sangat memperhatikan dan memang benar-benar menjaga nilai-nilai, dan norma budaya yang terkandung di dalamnya.

Akan tetapi, berdasarkan hasil pengamatan peneliti bahwa motif masyarakat desa Kemuja dalam pelaksanaan tradisi nganggung ini ada yang telah mengalami pergeseran, artinya tidak sesuai dengan motif karena adat-istiadat yang peneliti dapat dari hasil wawancara. Ada sebagian masyarakat di kalangan kelas atas atau ekonominya yang cukup lumayan bahwa dalam pelaksanaan tradisi ngangggung pada peringatan Maulid Nabi SAW mereka lebih 
mengutamakan makanan yang akan disajikan, seperti telah mengabaikan pemaknaan tradisi dan pemaknaan hari besar Maulid Nabi itu sendiri. Dan ada juga yang memang karena tuntutan peran sosial sebagai warga masyarakat desa Kemuja tersebut. Seperti masyarakat yang kurang mampu, bahwa mereka menyiapkan makanan seadanya. Bagi mereka yang terpenting bagaimana mengimplementasikan pemaknaan sesuai dengan motif, sehingga menjadi bagian dari masyarakat yang mempunyai peran bagi kelangsungan hidup masyarakat tersebut. Pemikiran Mead mengenai definisi singkat dari tiga ide dasar interaksi simbolik bahwa mind (pikiran) adalah kemampuan untuk menggunakan simbol yang mempunyai makna sosial yang sama, dimana tiap individu harus mengembangkan pikiran mereka melalui interaksi dengan individu lain. Nur dewi setyowati dalam http:// detaachtiana. blogspot.com/2013/04/reviewteoriinteraksionismesimbolik.Html.

Pemikiran ini jelas bahwa setiap individu masyarakat desa Kemuja memiliki kemampuan berfikir tentang makna simbol sosial tradisi Nganggung yang sangat bermanfaat bagi kelangsungan hidup bermasyarakat, sehingga melalui interaksi sosial terciptalah motif untuk melestarikan budaya dan adat-istiadat yang telah dibuat. Kemudian self (diri pribadi) adalah kemampuan untuk merefleksikan diri tiap individu dari penilaian sudut pandang atau pendapat orang lain. Manusia pada dasarnya kebanyakan tidak mengetahui kepribadian masing-masing, kecuali penilaian orang lain. Disinilah fungsi interaksi antar manusia yang bisa mengetahui bagaimana tindakan yang harus dilakukan. Masyarakat desa kemuja yang selalu berinteraksi baik melalui bahasa maupun simbol akan tercipta mind yang cerdas untu mengembangkan tindakan yang sesuai dengan makna sosial tradisi budaya nganggung sehingga motif yang tadinya telah tercipta maka akan terjaga.

Dan society (masyarakat) adalah hubungan sosial yang diciptakan, dibangun, dan dikonstruksikan oleh tiap individu ditengah masyarakat, dan tiap individu tersebut terlibat dalam perilaku yang mereka pilih secara aktif dan sukarela, yang pada akhirnya mengantarkan manusia dalam proses pengambilan peran di tengah masyarakatnya. Motif masyarakat desa Kemuja dalam pelaksanakan tradisi nganggung yang dapat menciptakan hubungan sosial antarindividu akan selalu dijalankan sesuai ketentuan yang telah dibuat, sehingga individu tersebut berperan dalam melestarikan adatistiadat tradisi budaya nganggung. Menurut Blumer dalam Kuswarno (2009: 113) pada premis pertama, yang mendasari pemikiran interaksionisme simbolik yaitu manusia bertindak terhadap sesuatu berdasarkan makna-makna yangada pada sesuatu itu bagi mereka. Dasar sebuah tindakan manusia memiliki pengertian yang sama dengan motif. Motif seperti pengertian di atas bahwa suatu dorongan yang ada dalam diri sendiri untuk berbuat sesuatu baik berupa gerakan maupun ucapan.

Berdasarkan pendapat Blumer di atas dan hasil wawancara yang telah dilakukan, dapat dikatakan bahwa tradisi budaya nganggung memiliki makna yang dikandungnya, makna tersebut dianggap baik bagi mereka sehingga masyarakat desa Kemuja ini bertindak bagaimana cara untuk mempertahankannya agar tetap utuh dan tidak hilang. Jadi jelaslah bahwa motif masyarakat desa Kemuja melaksanakan budaya nganggung merupakan upaya pelestarian budaya yang telah dilakoni secara turun- temurun serta telah menjadi kebiasaan (adat-istiadat) masyarakat setempat. Kebiasaan tersebut dilakukan atas dasar makna makna yang ada 
dalam budaya tersebut.

Sesuatu hal yang mengandung kebaikan akan membuat pikiran untuk berusaha menjadi bagian dari hal tersebut artinya setiap manusia memiliki keinginan dan kebutuhan dalam menjalankan tatanan kehidupannya, apalagi sesuatu yang baik dan wajib untuk dilaksanakan.

\section{Makna Simbol Tradisi Nganggung}

Setiap tradisi budaya memiliki simbol yang bermakna, tak terkecuali tradisi budaya nganggung. Tradisi budaya nganggung memiliki simbol-simbol yang bermakna. Simbol-simbol tersebut adalah simbol peralatan, simbol prosesi kegiatan dan simbol status sosial.

a. Makna simbol peralatan Tradisi Nganggung.

Makna simbol peralatan tradisi budaya Nganggung di desa Kemuja adalah suatu wujud rasa kebersamaan dan kepedulian yang dapat menciptakan persatuan dan kesatuan dalam masyarakat.

b. Makna simbol prosesi kegiatan Tradisi Nganggung pada peringatan Maulid Nabi SAW.

Makna simbol prosesi kegiatan tradisi nganggung adalah Sebagai wujud rasa syukur kepada Tuhan Yang Maha Esa dan ungkapan rasacinta, mengingat sifat-sifat agung Nabi Muhammad Saw, agar bisa meneladaninya

\section{c. Makna simbol status sosial Tradisi Nganggung.}

Makna simbol status sosial tradisi nganggung adalah perbedaan antara status sosial menengah keatas dan menengah ke bawah pada isi makanan yang disajikan. Esensi dari teori interaksi simbolik adalah simbol dan makna. Makna adalah hasil dari interaksi sosial. Ketika kita berinteraksi dengan orang lain, kita berusaha mencari makna yang cocok dengan orang tersebut. Langer memandang makna sebagai suatu hubungan yang kompleks diantara simbol, objek dan orang. Langer dalam Morissan dkk, (2009: 90).

Langer juga mengatakan bahwa kebutuhan simbolisasi atau penggunaan lambang merupakan salah satu kebutuhan pokok manusia. Lambang atau simbol adalah sesuatu yang digunakan untuk menunjuk sesuatu lainnya, berdasarkan kesepakatan sekelompok orang. Lambang meliputi kata-kata (pesan verbal), perilaku nonverbal, dan objek yang maknanya disepakati bersama (Mulyana, 2007: 92).

Makna simbol tradisi Nganggung yang memiliki berbagai macam jenis simbol dan makna, menandakan bahwa kekayaan tradisi budaya Ngangggung ini bukan hanya pada makna sosialnya, melainkan pada macam jenis simbol. Pernyataan ini sesuai dengan hasil pengamatan peneliti bahwa masyarakat desa Kemuja dalam pelaksanaannya masih menggunakan simbolsimbol peralatan yang telah ditentukan. Seperti dulang dan tudung saji. Mereka menganggap bahwa dengan menggunakan simbol yang telah ditentukan ini berarti telah memelihara dan melestarikan apa yang telah dititipkan oleh orang tua terdahulu. Akan tetapi ada sebagian masyarakat desa Kemuja dalam pelaksanaannya menggunakan peralatan yang lain seperti rantang. Mereka menganggap dengan menggunakan rantang lebih memudahkan untuk membawanya. Demikian halnya dengan simbol yang lain seperti simbol prosesi kegiatan yang membawa makanan, berzanji/bersholawat atas Nabi Saw dan berdo'a bersama-sama di masjid. Hal inilah yang merupakan kebiasaan dan adat-istiadat yang harus dilaksanakan.

Lain halnya dengan simbol status sosial seperti sekarang ini. Berdasarkan hasil 
pengamatan peneliti bahwa banyak masyarakat desa Kemuja yang melaksanakan tradisi nganggung hanya untuk kumpul-kumpul makan bersama, dan membuat makanan sebanyakbanyaknya. Akan tetapi ada juga masyarakat yang membuat makanan ala kadarnya sesuai dengan kemampuan mereka, sehingga dapat dibedakan mana yang berstatus menengah ke atas dan menengah ke bawah.

Melihat fenomena ini peneliti menyimpulkan bahwa telah terjadi pergeseran-pergeseran simbol tradisi nganggung, baik simbol peralatan, simbol prosesi kegiatan maupun simbol status sosial. Akan tetapi tidak menghilang makna yang sesungguhnya, tetap membawa pembelajaran bagi masyarakat akan kebersamaan dan kepedulian dalam hidup bermasyarakat.

Jika dihubungkan tentang pemikiran Mead di atas mengenai definisi singkat dari tiga ide dasar interaksi simbolik yaitu mind (pikiran), jelas bahwa di balik beragam simbol dan makna tradisi nganggung pasti memiliki makna sosial, tergantung setiap individu bagaimana merefleksikan makna simbol tersebut dengan individu lain agar tetap memiliki makna sosial yang sama. Kemudian self (diri pribadi), bagaimana tingkat keinginan individu untuk berinteraksi dengan sesama sehingga makna sosialnya dapat dijadikan sebagai contoh untuk bertindak dalam kehidupan bermasyarakat khususnya masyarakat desa Kemuja.

Dan Society (masyarakat). Simbol tradisi nganggung di desa Kemuja yang memiliki makna sosial pasti tercipta hubungan sosial. Hubungan tersebut selalu dipelihara dengan interaksi antar individu melalui simbol. Di sinilah terciptanya suatu tindakan yang selalu mengacu pada makna sosial yang telah dibuat, sehingga setiap individu masyarakatdesaKemuja tersebut memilikikonsep diri akan peranan sosial dalam menjalankan kehidupan bermasyarakat yang berbudaya. Pada premis kedua dalam Teori interaksi simbolik, Blumer pun mengatakan yang mendasari teori interaksi simbolik adalah makna tersebut berasal dari interaksi sosial seseorang dengan orang lain. Setiap interaksi yang berlangsung pada suatu tradisi budaya memiliki makna tertentu. Begitu pula yang terjadi pada tradisi budaya Nganggung di desa Kemuja Kecamatan Mendobarat.

Masyarakat desa Kemuja yang dalam kesehariannya telah membangun jiwa kebersamaan dan kepedulian terbentuk atas hasil interaksi antar individu melalui simbol yang bermakna sosial. Tindakan yang dilakukan pun berdasarkan makna sosial yang telah dibuat dengan kesepakatan bersama, sehingga memiliki peran sosial dalam menjaga eksistensi tradisi budaya nganggung di desa Kemuja itu sendiri. Berdasarkan hasil wawancara dan yang mendasari teori interaksi simbolik dia tas dapat dikatakan bahwa makna sosial simbol tradisi budaya nganggung di desa Kemuja merupakan hasil interaksi manusia yang kemudian dijadikan sebagai acuan untuk berinteraksi dalam kehidupan sehari-hari.

Dalam pelaksanaan tradisi nganggung terbentuk interaksi sosial dan tindakan sosial antar masyarakatsehinggaterciptalahkepribadiansetiap individu masyarakat desa kemuja yang sesuai dengan ajaran Islam. Seperti Islam mengajarkan kita tentang semua laku hidup begitu juga dengan makna simbol tradisi nganggung yang semuanya merupakan implementasi dari ajaran Islam yang harus dikerjakan.Setiap budaya memiliki sebuah simbol-simbol dan makna simbol-simbol tersebut terbentuk atas hasil karya manusia sebagai wujud kebersamaannya. Sehingga dijadikan sebagai acuan untuk masyarakat berinteraksi dan bertindak. Sesuai dengan apa yang dikatakan oleh Jerome Manis tentang tujuh hal mendasar yang 
besifat teoritis dan metodologis dari interaksi simbolik yaitu manusia dapat mengerti berbagai hal dengan belajar dari pengalaman dan persepsi seseorang selalu diterjemahkan dalam simbolsimbol.

\section{Implementasi Kegiatan Tradisi Nganggung}

Kegiatan tradisi budaya nganggung di desa Kemuja merupakan suatu pembelajaran tentang tata cara untuk bertindak, berinteraksi antarwarga masyarakat yang mempunyai nilai-nilai ajaran agama yang harus dilakukan dan terapkan dalam kehidupan sehari-hari. Berdasarkan hasil pengamatan peneliti bahwa masyarakat desa Kemuja yang mendapat pembelajaran akan kebersamaan dari pelaksanaan tradisi nganggung ini mereka terapkan dalam kehidupan seharihari. Hal ini terbukti dengan bentuk penerapan yang mereka lakukan seperti gotong-royong, keramah-tamahannya baik antar sesama maupun dengan masyarakat lain, tahlilan bersama-sama, Nganggung ke tempat warga yang meninggal, membudayakan silaturahmi, membudaya bersedekah baik materi maupun doa dan membudayakan rasa peduli antar sesama tanpa memandang ras serta selalu mendekatkan diri dengan lingkungan. Penerapan kegiatan tradisi nganggung yang dilakukan oleh masyarakat desa Kemuja merupakan suatu contoh bagi masyarakat Bangka ini umumnya. Betapa tidak dengan penerapan sebuah kegiatan tradisi yang memiliki makna sosial bagi pengembannya akan mempengaruhi dan menguatkan eksistensi tradisi budaya itu sendiri,malah dapat menumbuhkan benih-benih generasi yang memiliki adab, rasa peduli antar sesama dan rasa kebersamaan sehingga keselarasan antar anggota masyarakat terbina. Dan secara tidak langsung mereka telah melestarikan kebiasaan dan adat istiadat yang telah dititipkan kepada masyarakat Bangka ini umumnya.

Pemikiran Mead akan mind (pikiran), bahwa persepsi masyarakat desa Kemuja Kecamatan Mendobarat yang telah lama menjalankan tradisi budaya nganggung memiliki kemampuan untuk menerapkannya dalam kehidupan sehari-hari. Hal ini didukung makna sosial yang terkandung dalam tradisi nganggung melalui interaksi antarindividu. Semua itu terlihat ketika peneliti ke lapangan datang ke desa Kemuja tersebut bahwa mereka dengan mudah berinteraksi dengan peneliti sendiri yang peneliti awali dengan peminjaman sebuah korek api untuk merokok, dan mereka tidak segan-segan untuk mengundang datang ke rumahnya. Setelah itu peneliti merasa seperti teman lama yang sudah lama tidak bertemu. Kemudian Self(diri pribadi), dengan mengimplementasikan kegiatan tradisi Nganggung ini dalam kehidupan sehari-hari, sudah jelas bahwa masyarakat desa Kemuja telah menunjukkan kemampuan mereka sebagai pemegang amanah yang telah dititipkan orang tua terdahulu. Sehingga selaras dengan motif yang telah mereka katakan.

Dan society (masyarakat), pemikiran Mead yang terakhir ini semakin memperkuatkan motif masyarakat desa Kemuja dalam melaksanakan kegiatan tradisi Nganggung. Bahwa dengan mengimplementasikannya dalam kehidupan sehari-hari menunjukkan kemampuan mereka berinteraksi berdasarkan simbol yang mengandung makna sosial. Menurut Blumer pada premis ketiga, yang mendasari teori interaksi simbolik adalah makna-makna tersebut disempurnakan di saat proses interaksi sosial berlangsung. Berdasarkan hasil wawancara dan teori di atas bahwa kegiatan tradisi nganggung yang berisikan makna sosial diimplementasikan oleh segenap masyarakat dalam kehidupan sehari-hari. Artinya setiap interaksi yang sedang 
berlangsung kesadaran diri harus siap dalam menterjemahkan bagaimana makna sosial yang telah dipelajari agar berjalan sesuai dengan tujuan. Untuk mencapai suatu tujuan itu memang tidak mudah, terkadang berbagai hambatan dan rintangan untuk mempengaruhi keinginan kita baik di luar diri maupun dalam diri. Dalam diri terdapat naluri egois, nafsu yang mengagalkan setiap tujuan kita, apalagi tujuan tersebut hal kebaikan.

Mengimplementasikan berarti kita ingin merefleksikan makna sesuatu yang ada padanya. Makna sosial yang terkandung dalam tradisi budaya Nganggung merupakan suatu tujuan hidup yang hakiki, yang di dalam tercipta kepribadian setiap individu akan kebersamaan, kepedulian antarsesama, jiwa gotong royong, serta dapat mempererat tali silaturahmi, persaudaraan sehingga menciptakan hubungan yang harmonis, kerukunan hidup beragama dan bermasyarakat serta membina persatuan dan kesatuan. Untuk meraih tujuan tersebut masyarakat desa Kemuja ini mengimplementasikannya dengan membudayakan silaturahmi, membudayakan gotong royong, membudayakan kebersamaan dalam hal kemasyarakatan maupun agama, usaha agar selalu melihat ke belakang artinya peduli dengan warga yang sedang membutuhkan bantuan, baik anak yatim, maupun ada yang meninggal.

\section{KESIMPULAN}

Berdasarkan hasil penelitian dan analisis data yang telah dilakukan,maka dapat disimpulkan bahwa:

\section{Motif Tradisi Nganggung}

Motif masyarakat desa Kemuja kecamatan Mendobarat dalam melaksanakan tradisi budaya nganggung adalah untuk melestarikan kebiasaan adat dan istiadat yang telah lama dilakukan oleh tetuah terdahulu agar tidak mudah hilang dimakan zaman baik maknanya maupun bentuk pelaksanaannya. Meskipun telah terjadi perubahan seiring perkembangan masyarakat akan pemaknaan yang sesungguhnya.

\section{Makna Simbol Tradisi nganggung}

Makna simbol tradisi budaya nganggung di desa Kemuja adalah sebagai wujud rasa syukur atas nikmat yang diberikan Yang Maha Kuasa (sedekah), menjalin tali silaturahmi dan wujud rasa kebersamaan. Mengajarkan manusia bertingkah laku dengan baik dalam kehidupan sehari-hari baik kehidupan beragama maupun masyarakat, dan menciptakan kepribadian setiap individu akan kebersamaan dan kepedulian, serta dapat mempererat tali silaturahmi, tali persaudaraan sehingga tercipta hubungan yang harmonis, kerukunan hidup beragama maupun bermasyarakat dan persatuan dan kesatuan.

\section{Implementasi Kegiatan Tradisi Nganggung}

Implementasi kegiatan tradisi nganggung yang dilakukan oleh masyarakat di desa Kemuja merupakan suatu bentuk ungkapan rasa syukur terutama kepada Tuhan Yang Maha Esa, yang telah memberikan ajaran kebaikan kepada kekasihNya Nabi Muhammad SAW hingga ke umatnya sampai sekarang masih terjaga. Bentuk penerapan yang mereka lakukan seperti gotong royong, keramah-tamahannya baik antar sesama maupun dengan masyarakat lain, membawa makanan bersama-sama ke masjid, tahlilan bersama-sama, do'a bersama, nganggung ke tempat warga yang meninggal, membudayakan silaturahmi, membudaya bersedekah baik materi maupun doa dan membudayakan rasa peduli antar sesama tanpa memandang ras serta selalu mendekatkan diri dengan lingkungan.

\section{SARAN}

Budaya nganggung merupakan salah satu 
tradisi yang harus dilestarikan keberadaannya, baik di masa sekarang maupun di masa yang akan datang, karena nilai-nilai yang terkandung dalam tradisi tersebut merupakan nilai-nilai kebaikan yang telah diwariskan oleh para pendahulu dan merupakan nilai-nilai ajaran Islam yang harus diterapkan dalam kehidupan sehari-hari. Agar identitas tradisi nganggung ini tetap utuh seperti semula maka masyarakat desa Kemuja harus memperhatikan pertransferan pesan kepada regenerasi yang akan datang, karena jika ada perubahan sedikit apapun dalam pelaksanaan atau penerapannya maka lama kelamaan akan hilang makna yang sesungguhnya dan pelaksanaannya hanya sekedar prosesi saja.

\section{DAFTAR PUSTAKA}

Andy Corry Wardhani, Morissan. 2009. Teori Komunikasi. Jakarta: Ghalia Indonesia.

Arikunto, Suharsimi. 2005. Manajemen Penelitian. Jakarta: Renika Cipta.

Azwar, Saifuddin. 2007. Metode Penelitian. Yogyakarta: Pusaka Pelajar.

Indranata, Iskandar. 2008. Pendekatan kualitatif untuk Pengendalian Kualitas. Jakarta: Universitas Indonesia.

Kriyantono, Rachmat. 2007. Teknik Praktis Riset Komunikasi. Jakarta: Kencana Prenada Media Group.

Koentjaraningrat. 2009. Pengantar Ilmu Antropologi. Jakarta: Rineka Cipta.

Kuswarno, Engkus. 2009. METODE Komunikasi FENOMENOLOGI

Konsepsi, Pedoman, dan Contoh Penelitiannya. Bandung: Widya Padjadjaran.

Liliweri, Alo. 2009. Dasar-dasar Komunikasi Antar Budaya. Yogyakarta: Pusaka Pelajar. Mulyana, Deddy. 2007. Ilmu Komunikasi Suatu Pengantar. Bandung: PT. Remaja
Rosdakarya. 2006. Metode Penelitian

Kualitatif. Bandung: PT. Remaja Rosdakarya. .

Sobur, Alex. 2006. Semiotika Komunikasi. Bandung: Rosdakarya.

Sugiyono. 2009. Metode Penelitian Kualitatif (kualitatif R\&D). Bandung: Alfabela.

Suradinata, Ermaya, 1996, Manajemen Sumber Daya Manusia Tinjauan. Bandung: Ramadhan.

Purwadarminta, W.J.S, 1991, Kamus Umum Bahasa Indonesia. Jakarta: Balai Pustaka.

Zuriah, Nurul. 2009, METODE Sosial dan Pendidikan, Teori Aplikasi. Jakarta: PT. Bumi Aksara

\section{Sumber Internet:}

Abdul Aziz. 2009. Makna Simbol Ritual dalam Ritual Agung Sejarah Alam Ngaji Rasa di Komunitas Bumi Segandu Dermayu. Yogyakarta. (Online). http:// digilib.uinsuka.ac.id/3932/1/BAB\%20 I\%2CV\%2C\%20DAFTAR\%20PUSTAKA. pdf. Diakses 02 November 2012

Arif Sobarudin. 2012. http://www.bisosial. com/2012/11/kebiasaan-custom.html. (Online). Diakses 12 Januari 2014

Endang Sri Handayani. 2007, Makna Simbolis Bentuk Penyajian Wayang Wong Sakral Dalam Upacara Tradisi Bulan Suro. Magelang. (Online). http: //www. Pustaka skripsi. com/ download. php? file $=2459$. diakses 02

November 2012

Jaka Filyamma. 2012. (Online). http: // jakafil yamma. blogspot. com/2012/09/ nganggung-tradisi-bangka-belitung. html. Diakses 18 November 2013.

Kompasiana. 2010. (Online). http://sosbud. kompasiana. com/2010/07/31/ 
kenduriantara-

tradisi-dan-agama-208380.html. Diakses.

03 Desember 2014

Martha Gunawan. 2012. (Online). http: // marthagunawan. blogspot. com/2012/

06/makna-pelestarian-budaya.html. Diakses

13 Januari 2014

Nur dewi setyowati. 2013. (Online). http: // detaachtiana. blogspot. com/2013/

04/review-teori-interaksionisme-simbolik. html. Diakses 05 januari 2014.

Pengertian ahli. (Online). http://www. pengertiparaahli.com/p/blog-page 20. html. Diakses 23 Desember 2014

Wikipedia bahasa Indonesia, ensiklopedia bebas.

(Online). (http: // id. wikipedia. org/wiki/Maulid_Nabi_Muhammad).

Diakses 2 juni 2013

Wikipedia. (Online). http: // id. wikipedia. org/ wiki/ Tradisi. Diakses 21 Januari

2014

\section{Sumber Lainnya:}

Arsip kantor desa Kemuja kecamatan Mendobarat Kabupaten Bangka. 